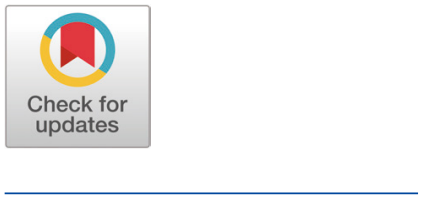

Received: Dec 26, 2019

Revised: Mar 23, 2020

Accepted: Mar 23, 2020

${ }^{*}$ Corresponding author

Yoo Yong Kim

Department of Agricultural

Biotechnology, and Research Institute

of Agriculture and Life Sciences,

Seoul National University, Seoul 08826,

Korea.

Tel: +82-2-880-4801

E-mail: yooykim@snu.ac.kr

Copyright $\odot 2020$ Korean Society of Animal Sciences and Technology.

This is an Open Access article distributed under the terms of the Creative Commons Attribution

Non-Commercial License (http:// creativecommons.org/licenses/by$\mathrm{nc} / 4.0 /$ ) which permits unrestricted non-commercial use, distribution, and reproduction in any medium, provided the original work is properly cited.

ORCID

Jinsu Hong

https://orcid.org/0000-0002-3401-3024

Lin Hu Fang

https://orcid.org/0000-0002-3617-7583

Yoo Yong Kim

https://orcid.org/0000-0001-8121-3291

Competing interests

No potential conflict of interest relevant

to this article was reported.

Funding sources

This research was supported by

"Cooperative Research Program

\section{Effects of dietary energy and lysine levels on physiological responses, reproductive performance, blood profiles, and milk composition in primiparous sows}

\author{
Jinsu Hong ${ }^{1,2}$, Lin Hu Fang ${ }^{1}$ and Yoo Yong Kim ${ }^{1 *}$ \\ ${ }^{1}$ Department of Agricultural Biotechnology, and Research Institute of Agriculture and Life Sciences, \\ Seoul National University, Seoul 08826, Korea \\ ${ }^{2}$ Department of Animal Science, South Dakota State University, Brookings 57007, USA
}

\section{Abstract}

The adequate intake of energy and lysine for primiparous sows are necessary for maternal growth of sows and growth of their progeny. This study was conducted to evaluate the effects of dietary energy and lysine levels on primiparous sows and their progeny. A total of 48 gilts (Yorkshire $\times$ Landrace), with an initial body weight (BW) of $168.1 \pm 9.71 \mathrm{~kg}$ and at day 35 of gestation, were allotted to eight treatment groups with a $2 \times 4$ factorial arrangement. The first factor was metabolizable energy levels in diet $(3,265$ or $3,365 \mathrm{kcal}$ of $\mathrm{ME} / \mathrm{kg})$, and the second factor was lysine levels in diet (gestation $0.55 \%, 0.65 \%, 0.75 \%, 0.85 \%$, lactation $0.70 \%$, $0.85 \%, 1.00 \%, 1.15 \%)$. The BW gain $(p=0.07)$ and backfat thickness $(p=0.09)$ in the gestation period showed a tendency to be increased in sows fed the high-energy diets. In the lactation period, sows fed the high-energy diets tended to be greater BW $(p=0.09)$ and less BW loss $(p=0.05)$ than those of sows fed the low-energy diets. Sows fed high-energy diets had a tendency of greater piglet weight at day 21 of lactation and greater piglet weight gain ( $p=0.08$ and $p=0.08$, respectively). Although the blood urea nitrogen (BUN) was increased linearly as dietary lysine level increased at day 110 of gestation (Linear, $p=0.03$ ), the BUN was decreased linearly as dietary lysine level increase at day 21 of lactation (Linear, $p<0.01$ ). In the composition of colostrum, sows fed high-energy diets had greater casein, protein, total solid, solid not fat, and free fatty acid concentrations than those of sows fed low-energy diets ( $p$ $<0.05$ ). Supplementation of total lysine $0.75 \%$ for gestation and $1.00 \%$ for lactation with 3,365 $\mathrm{kcal}$ of $\mathrm{ME} / \mathrm{kg}$ energy level could be applied to the primiparous sows' diet to improve performance of sows and growth of their progeny.

Keywords: Energy, Lysine, Physiological responses, Primiparous sows, Reproductive performance 
for Agriculture Science and Technology Development (Project No. PJ011617)" Rural Development Administration, Korea.

Acknowledgements Not applicable.

Availability of data and material Upon reasonable request, the datasets of this study can be available from the corresponding author.

Authors' contributions

Conceptualization: Hong J, Kim YY.

Data curation: Hong J.

Formal analysis: Hong J.

Methodology: Hong J, Fang LH.

Software: Hong J.

Validation: Hong J, Fang LH, Kim YY.

Investigation: Hong J, Fang LH.

Writing- original draft: Hong J.

Writing-review \& editing: Fang LH, Kim YY.

Ethics approval and consent to participate All experimental procedures were reviewed and approved by the Institutional Animal Care and Use Committee at Seoul National University (SNU-160819-9).

\section{INTRODUCTION}

The recent genetic improvement in sows have resulted in a high litter size and low piglet birth weight and uniformity [1-3]. The modern sows need higher nutrient intake to support the maternal body reserve and maintain the growth requiremnet of their progeny during the gestation and lactation periods rather than ordinary sows due to the increased growth rate and number of fetuses.

The adequate intake of nutrients such as energy and lysine are an important part of the nutrition for sows [4]. Deficient energy intake during gestation has been identifeid as the major reason for decreased body fat reserve at farrowing or weaning, which prolongs the weaning-to-estrus interval (WEI) and decreases the conception rate [5,6]. On the other side, the excessive energy intake in gestating sows increased body weight of sows at farrowing [7] and the excessive weight gain could have a negative influence on litter size, lactation feed intake, and subsequent parity performance [810]. Several studies have reported that low lysine intake in lactation period had negative influences on metabolic status, reproductive hormone secretion, and WEI [11-13]. On the other hand, high lysine intake improved the metabolic status of sows and increased the total litter weight at birth and piglet weight at weaning [14-16].

Although there have been several studies on dietary energy and lysine levels in first parity $[10,12,17,18]$, the research on amino acid utilization in primiparous sows was limited. The amino acids utilization for primiparous sows should be considered with the maternal growth, development of mammary gland, and fetal growth during gestation and milk production and maternal nutrient mobilization during lactation [19], hence the amino acids requirement for primiparous sows is greater than multiparous sows $[19,20]$. Furthermore, it is very important to provide adequate energy and amino acids to primiparous sows because body status and performance of primiparous sows have a significant impact on later productivity and longevity [21,22].

The lysine requirement of primiparous sows has been estimated to be $2.1 \mathrm{~g} / \mathrm{d}$ for maintenance, 5.5 $\mathrm{g} / \mathrm{d}$ for maternal growth, and $4.4 \mathrm{~g} / \mathrm{d}$ for growth of the conceptus and reproductive tissues [23,24]. As reported by the NRC [25], the total lysine requirement increased from $0.57 \%$ to $0.80 \%$ in gestation and from $0.91 \%$ to $0.93 \%$ in lactation. Also, NRC [25] suggested that the optimal lysine intake was $12.4 / 19.3 \mathrm{~g} / \mathrm{d}(<90 \mathrm{~d},>90 \mathrm{~d})$ and 52.6 to $56.5 \mathrm{~g} / \mathrm{d}$ in gestation and lactation of primiparous sows, respectively.

Therefore, it was hypothesized that adequate intake of energy and lysine during gestation and lactation will improve the reproductive performance and litter performance of primiparous sows. Thus, this experiment was conducted to investigate the effect of the dietary energy and lysine levels on the physiological response, reproductive performance, blood profiles, and milk composition of primiparous sows.

\section{MATERIALS AND METHODS}

All experimental procedures were reviewed and approved by the Institutional Animal Care and Use Committee at Seoul National University (SNU-160819-9).

\section{Animal preparation}

A total of 48 gilts (initial body weight [BW] of $90 \mathrm{~kg}$; F1, Yorkshire $\times$ Landrace; Darby, Korea) were obtained from a research farm of Seoul National University (Eumseong, Korea). They were group-housed in a separate pen $(11 \mathrm{~m} \times 14 \mathrm{~m})$ and offered feed and fresh water ad libitum until reaching $120 \mathrm{~kg}$ BW. When the BW of gilts reached $120 \mathrm{~kg}$, the gilts were moved to a breeding barn and housed in the gestation stalls $(2.20 \mathrm{~m} \times 0.65 \mathrm{~m})$ with a concrete slatted floor. The sows 
were fed a gestation diet of $800 \mathrm{~g} / \mathrm{d}$ for an average daily gain of $750 \mathrm{~g} / \mathrm{d}$. The estrus and heat detection for gilts were diagnosed twice a day with two mature boars (Duroc) using the back-pressure test. After three or four estrus cycles, the gilts with average BW from 135 to $140 \mathrm{~kg}$ were given artificial insemination with fresh diluted semen (Darvy AI center, Chungju, Korea) twice in $12 \mathrm{hrs}$ intervals. The confirmation of pregnancy was performed at 21 days of gestation by re-estrus checks and at 35 days of gestation by an ultrasound diagnostic device (Easyscan, Dongjin BLS, Gwangju, Gyeonggi-do, Korea).

\section{Experimental animals and housing}

The 48 primiparous sows (average BW of $168.1 \pm 9.71 \mathrm{~kg}$ ) with confirmed pregnancy were used for a feeding trial. The pregnant sows were allotted to eight treatments based on BW and backfat (BF) thickness at day 35 of gestation in a completely randomized design (CRD) with six replicates. The gestating sows were housed in an individual gestation stall $(2.20 \mathrm{~m} \times 0.65 \mathrm{~m})$ equipped with a feeder and a water nipple until day 110 of gestation. On day 110 of gestation, the pregnant sows were moved into the farrowing barn after washing their body and placed in individual farrowing crates $(2.50 \mathrm{~m} \times 1.80 \mathrm{~m})$. Each farrowing crate was equipped with a cup drinker and a feeder and a piglet house with a heating lamp and a waterer. The room temperature was maintained at an average of 20 $\pm 3^{\circ} \mathrm{C}$ and $28 \pm 2{ }^{\circ} \mathrm{C}$ for gestating and lactating sows, respectively. The piglet houses under heating lamps were kept at $32 \pm 2^{\circ} \mathrm{C}$. The gestating sows were fed $2.0 \mathrm{~kg} / \mathrm{d}$ of the experimental diet for gestation period once per day (08:00), and feed was reduced gradually by $0.2 \mathrm{~kg} / \mathrm{d}$ for 5 days before the due date of farrowing. After farrowing, the amount of feeding lactation diet was gradually increased from 1 to $5 \mathrm{~kg} / \mathrm{d}$ during the first 5 days of lactation; then, sows were fed the experimental diet for lactation period ad libitum until weaning.

\section{Experimental design and diets}

The experiment was designed as a $2 \times 4$ factorial arrangement with the metabolizable energy level and the total lysine level in diet as the main factors. The experimental diets for gestation period contained two energy levels $[3,265$ or $3,365 \mathrm{kcal}$ of metabolizable energy (ME) $/ \mathrm{kg}]$ and different total lysine levels (total lysine $0.55 \%, 0.65 \%, 0.75 \%, 0.85 \%$ or $11.0 \mathrm{~g} / \mathrm{d}, 13.0 \mathrm{~g} / \mathrm{d}, 15.0 \mathrm{~g} / \mathrm{d}$, and 17.0 $\mathrm{g} / \mathrm{d})$. The lactation diets contained two energy levels (3,265 or 3,365 kcal of ME/ $/ \mathrm{kg}$ ) and different total lysine levels (total lysine $0.70 \%, 0.85 \%, 1.00 \%$, and $1.15 \%$ ). All nutrients of the experimental diets met or exceeded the recommendations of the NRC [12]. The diet formulation and chemical composition for the experimental diets were presented in Tables 1 and 2.

\section{Sample collection and analysis}

The sow BW and BF thickness were measured at 35 and 110 days of gestation, 24 hrs postpartum, and 21 days of lactation. The BW was measured by an electric scale (CAS, Yangju, Korea) and BF thickness was measured at $\mathrm{P}_{2}$ position by an ultrasound lean meter (Anyscan BF, Songkang GLC, Seongnam, Korea). In lactation period, the feed supply and wastage were recorded to measure the voluntary feed intake of lactating sows. The days from weaning to first estrus of sows were recorded to calculate the weaning to estrus interval (WEI).

Within 12 hrs postpartum, the number of piglets in total born, born alive, stillborn, and mummy, and their BWs were recorded, respectively. At 21 days of lactation, the BW of piglets were measured for litter weight gain and piglet weight gain. The piglet birth weights and piglet BWs at 21 days of lactation from one litter was used for calculating piglet uniformity, such as coefficient of variation $(\mathrm{CV})$ and standard deviation $(\mathrm{SD})$.

The $10 \mathrm{~mL}$ of blood sample $(\mathrm{n}=4$ for each treatment except two sows from the highest BW 
Table 1. The formulas and chemical composition of experimental gestation diet ${ }^{1)}$

\begin{tabular}{|c|c|c|c|c|c|c|c|c|}
\hline \multirow{2}{*}{ Item } & \multicolumn{4}{|c|}{ ME $3,265 \mathrm{kcal} / \mathrm{kg}$} & \multicolumn{4}{|c|}{ ME $3,365 \mathrm{kcal} / \mathrm{kg}$} \\
\hline & Lys $0.55 \%^{1)}$ & Lys $0.65 \%$ & Lys $0.75 \%$ & Lys $0.85 \%$ & Lys $0.55 \%$ & Lys $0.65 \%$ & Lys $0.75 \%$ & Lys $0.85 \%$ \\
\hline \multicolumn{9}{|l|}{ Ingredients (\%) } \\
\hline Corn & 77.03 & 77.17 & 77.34 & 77.53 & 71.96 & 72.09 & 72.27 & 72.53 \\
\hline Soybean meal & 13.12 & 12.79 & 12.46 & 12.13 & 12.97 & 12.64 & 12.31 & 12.00 \\
\hline Wheat bran & 1.99 & 2.05 & 2.08 & 2.05 & 3.90 & 3.96 & 3.97 & 3.93 \\
\hline Palm kernel meal & 3.00 & 2.04 & 2.98 & 3.02 & 3.86 & 3.87 & 3.87 & 3.85 \\
\hline Tallow & 1.54 & 1.52 & 1.49 & 1.46 & 4.03 & 4.01 & 3.98 & 3.94 \\
\hline L-Lysine $\mathrm{HCl}(78 \%)$ & 0.00 & 0.13 & 0.27 & 0.40 & 0.00 & 0.13 & 0.27 & 0.40 \\
\hline DL-Methionine (99\%) & 0.03 & 0.03 & 0.04 & 0.04 & 0.03 & 0.04 & 0.04 & 0.04 \\
\hline L-Threonine (99\%) & 0.01 & 0.02 & 0.02 & 0.03 & 0.02 & 0.02 & 0.03 & 0.03 \\
\hline L-Tryptophan (10\%) & 0.09 & 0.11 & 0.13 & 0.15 & 0.08 & 0.09 & 0.11 & 0.13 \\
\hline MDCP & 1.44 & 1.44 & 1.44 & 1.44 & 1.38 & 1.38 & 1.38 & 1.38 \\
\hline Limestone & 1.15 & 1.15 & 1.15 & 1.15 & 1.17 & 1.17 & 1.17 & 1.17 \\
\hline Vit. $\mathrm{mix}^{2)}$ & 0.10 & 0.10 & 0.10 & 0.10 & 0.10 & 0.10 & 0.10 & 0.10 \\
\hline Min. $\mathrm{mix}^{3)}$ & 0.10 & 0.10 & 0.10 & 0.10 & 0.10 & 0.10 & 0.10 & 0.10 \\
\hline Choline-Cl (50\%) & 0.10 & 0.10 & 0.10 & 0.10 & 0.10 & 0.10 & 0.10 & 0.10 \\
\hline Salt & 0.30 & 0.30 & 0.30 & 0.30 & 0.30 & 0.30 & 0.30 & 0.30 \\
\hline Total & 100.00 & 100.00 & 100.00 & 100.00 & 100.00 & 100.00 & 100.00 & 100.00 \\
\hline \multicolumn{9}{|l|}{ Chemical composition $^{4)}$} \\
\hline $\mathrm{ME}(\mathrm{kcal} / \mathrm{kg})$ & $3,265.07$ & $3,265.03$ & $3,265.02$ & $3,265.00$ & $3,365.04$ & $3,365.04$ & $3,365.02$ & $3,365.03$ \\
\hline Crude protein (\%) & 12.15 & 12.15 & 12.15 & 12.15 & 12.15 & 12.15 & 12.15 & 12.15 \\
\hline Total lysine (\%) & 0.55 & 0.65 & 0.75 & 0.85 & 0.55 & 0.65 & 0.75 & 0.85 \\
\hline Total methionine (\%) & 0.23 & 0.23 & 0.23 & 0.23 & 0.23 & 0.23 & 0.23 & 0.23 \\
\hline Total threonine (\%) & 0.48 & 0.48 & 0.48 & 0.48 & 0.48 & 0.48 & 0.45 & 0.48 \\
\hline Total tryptophan (\%) & 0.13 & 0.13 & 0.13 & 0.13 & 0.13 & 0.13 & 0.11 & 0.13 \\
\hline Calcium (\%) & 0.75 & 0.75 & 0.75 & 0.75 & 0.75 & 0.75 & 0.75 & 0.75 \\
\hline Total phosphorus (\%) & 0.60 & 0.60 & 0.60 & 0.60 & 0.60 & 0.60 & 0.60 & 0.60 \\
\hline
\end{tabular}

${ }^{1)}$ Experimental diet was formulated with corn-soybean meal (SBM) based diet and adjusted lysine content.

${ }^{2)}$ Provided per kg of diet: vitamins per kg of complete diets: vitamin A, 8,000 IU; vitamin $\mathrm{D}_{3}, 1,600 \mathrm{IU}$; vitamin E, $32 \mathrm{IU}$; d-biotin, $64 \mathrm{~g}$; riboflavin, $3.2 \mathrm{mg}$; calcium pantothenic acid, 8 $\mathrm{mg}$; niacin, $16 \mathrm{mg}$; vitamin $\mathrm{B}_{12}, 12 \mu \mathrm{g}$; vitamin $\mathrm{K}, 2.4 \mathrm{mg}$.

${ }^{3)}$ Provided per kg of diet: mineral per kg of complete diet: Se, $0.1 \mathrm{mg} ; \mathrm{I}, 0.3 \mathrm{mg}$; Mn, $24.8 \mathrm{mg}$; Cu, $54.1 \mathrm{mg}$; Fe, $127.3 \mathrm{mg}$; Zn, $84.7 \mathrm{mg}$; Co, $0.3 \mathrm{mg}$.

${ }^{4)}$ Calculated value.

ME, metabolizable energy; Lys, lysine; MDCP, mono-dicalcium phosphate.

and the lowest BW) was collected from the jugular vein of each sow with a serum tube (SST ${ }^{\mathrm{TM}} \mathrm{II}$ Advance, BD Vacutainer, Becton Dickinson, Plymouth, UK) and centrifuged at 1,957 $\mathrm{xg}$ and $4{ }^{\circ} \mathrm{C}$ for 15 minutes (5810R, Eppendorf, Hamburg, Germany). Then, the serum was transferred into microtubes (Axygen, Union City, CA, USA) and stored frozen at $-20^{\circ} \mathrm{C}$ for further analysis. The concentration of total protein (colorimetry, TP2, Roche, Germany), creatinine (kinetic colorimetry assay, CREJ2, Roche, Germany), blood urea nitrogen (BUN; kinetic UV assay, UREAL, Roche, Germany).

Colostrum at 12 hrs postpartum and milk at day 21 of lactation were collected from the first and second teats of sows ( $\mathrm{n}=4$ for each treatment with the same sows for blood sampling) after a $5 \mathrm{IU}$ oxytocin injection (Komi oxytocin inj., Komipharm International, Siheung, Korea) in the ear vein. Collected milk samples were stored frozen at $-20^{\circ} \mathrm{C}$ until later analysis. The composition of colostrum and milk (day 21) were analyzed by using Milkoscan FT 120 (FOSS, Hillerod, Denmark) in 
Table 2. The formulas and chemical composition of experimental lactation diet

\begin{tabular}{|c|c|c|c|c|c|c|c|c|}
\hline \multirow{2}{*}{ Item } & \multicolumn{4}{|c|}{ ME $3,265 \mathrm{kcal} / \mathrm{kg}$} & \multicolumn{4}{|c|}{ ME $3,365 \mathrm{kcal} / \mathrm{kg}$} \\
\hline & Lys $0.70 \%$ & Lys $0.85 \%$ & Lys $1.00 \%$ & Lys $1.15 \%$ & Lys $0.70 \%$ & Lys $0.85 \%$ & Lys $1.00 \%$ & Lys $1.15 \%$ \\
\hline \multicolumn{9}{|l|}{ Ingredients (\%) } \\
\hline Corn & 71.46 & 71.87 & 72.23 & 72.62 & 69.22 & 69.59 & 69.99 & 70.39 \\
\hline Soybean meal & 18.02 & 17.98 & 17.96 & 17.92 & 18.20 & 18.28 & 18.37 & 18.37 \\
\hline Wheat bran & 2.00 & 2.00 & 2.00 & 2.00 & 1.88 & 1.89 & 1.89 & 1.89 \\
\hline Sesame meal & 4.00 & 3.49 & 3.00 & 2.48 & 4.22 & 3.64 & 2.99 & 2.40 \\
\hline Palm kernel meal & 0.00 & 0.00 & 0.00 & 0.00 & 0.00 & 0.00 & 0.00 & 0.00 \\
\hline Tallow & 1.39 & 1.31 & 1.24 & 1.16 & 3.37 & 3.29 & 3.21 & 3.13 \\
\hline L-Lysine $\mathrm{HCl}(78 \%)$ & 0.00 & 0.19 & 0.38 & 0.58 & 0.00 & 0.18 & 0.37 & 0.57 \\
\hline DL-Methionine (99\%) & 0.01 & 0.01 & 0.01 & 0.02 & 0.01 & 0.01 & 0.01 & 0.02 \\
\hline L-Threonine (99\%) & 0.02 & 0.03 & 0.03 & 0.04 & 0.02 & 0.02 & 0.03 & 0.04 \\
\hline L-Tryptophan (10\%) & 0.22 & 0.22 & 0.22 & 0.22 & 0.20 & 0.20 & 0.20 & 0.21 \\
\hline MDCP & 1.20 & 1.21 & 1.23 & 1.25 & 1.20 & 1.22 & 1.25 & 1.28 \\
\hline Limestone & 1.08 & 1.09 & 1.10 & 1.11 & 1.08 & 1.08 & 1.09 & 1.10 \\
\hline Vit. $\operatorname{mix}^{1)}$ & 0.10 & 0.10 & 0.10 & 0.10 & 0.10 & 0.10 & 0.10 & 0.10 \\
\hline Min. mix $^{2)}$ & 0.10 & 0.10 & 0.10 & 0.10 & 0.10 & 0.10 & 0.10 & 0.10 \\
\hline Choline-Cl (50\%) & 0.10 & 0.10 & 0.10 & 0.10 & 0.10 & 0.10 & 0.10 & 0.10 \\
\hline Salt & 0.30 & 0.30 & 0.30 & 0.30 & 0.30 & 0.30 & 0.30 & 0.30 \\
\hline Total & 100.00 & 100.00 & 100.00 & 100.00 & 100.00 & 100.00 & 100.00 & 100.00 \\
\hline \multicolumn{9}{|l|}{ Chemical composition $^{3)}$} \\
\hline $\mathrm{ME}(\mathrm{kcal} / \mathrm{kg})$ & $3,265.02$ & $3,265.03$ & $3,265.04$ & $3,265.07$ & $3,365.04$ & $3,365.06$ & $3,365.04$ & $3,365.00$ \\
\hline Crude protein (\%) & 15.20 & 15.20 & 15.20 & 15.20 & 15.20 & 15.20 & 15.20 & 15.20 \\
\hline Total lysine (\%) & 0.70 & 0.85 & 1.00 & 1.15 & 0.70 & 0.85 & 1.00 & 1.15 \\
\hline Total methionine (\%) & 0.25 & 0.25 & 0.25 & 0.25 & 0.25 & 0.25 & 0.25 & 0.25 \\
\hline Total threonine (\%) & 0.62 & 0.62 & 0.62 & 0.62 & 0.62 & 0.62 & 0.62 & 0.62 \\
\hline Total tryptophan (\%) & 0.18 & 0.18 & 0.18 & 0.18 & 0.18 & 0.18 & 0.18 & 0.18 \\
\hline Calcium (\%) & 0.75 & 0.75 & 0.75 & 0.75 & 0.75 & 0.75 & 0.75 & 0.75 \\
\hline Total phosphorus (\%) & 0.60 & 0.60 & 0.60 & 0.60 & 0.60 & 0.60 & 0.60 & 0.60 \\
\hline
\end{tabular}

${ }^{1)}$ Provided per kg of diet: vitamins per kg of complete diets: vitamin A, 8,000 IU; vitamin $D_{3}, 1,600 \mathrm{IU}$; vitamin E, $32 \mathrm{IU}$; d-biotin, $64 \mathrm{~g}$; riboflavin, 3.2 mg; calcium pantothenic acid, 8 mg; niacin, $16 \mathrm{mg}$; vitamin $\mathrm{B}_{12}, 12 \mu \mathrm{g}$; vitamin $\mathrm{K}, 2.4 \mathrm{mg}$.

${ }^{2)}$ Provided per kg of diet: mineral per kg of complete diet: Se, 0.1 mg; I, 0.3 mg; Mn, 24.8 mg; Cu, 54.1 mg; Fe, 127.3 mg; Zn, 84.7 mg; Co, 0.3 mg.

${ }^{3)}$ Calculated value.

ME, metabolizable energy; Lys, lysine; MDCP, mono-dicalcium phosphate.

the National Institute of Animal Science (Wanju, Korea).

\section{Statistical analysis}

Data were analyzed by least squares mean comparisons and were evaluated using PDIFF option with the general linear model (GLM) procedure of SAS (SAS Inst., Cary, NC, USA). Individual sows and their litters were used as the experimental units. Orthogonal polynomial contrasts were used to detect the linear and quadratic responses to lysine levels when the significance of lysine effect was detected. To test the hypotheses, $p<0.05$ was considered significant. If pertinent, trends $(0.05$ $\leq p<0.10$ ) are also reported. 
Table 3. Effects of dietary energy and lysine levels on physiological changes, feed intake, and WEl in primiparous sows

\begin{tabular}{|c|c|c|c|c|c|c|c|c|c|c|c|c|}
\hline \multirow[b]{2}{*}{ Item $^{1)}$} & \multicolumn{4}{|c|}{ ME 3,265 kcal/kg } & \multicolumn{4}{|c|}{ ME 3,365 kcal/kg } & \multirow[b]{2}{*}{ SEM } & \multicolumn{3}{|c|}{$p$-value } \\
\hline & $\begin{array}{c}\text { Lys } \\
0.55 \\
0.70 \\
\%\end{array}$ & $\begin{array}{c}\text { Lys } \\
0.65 \\
0.85 \\
\%\end{array}$ & $\begin{array}{c}\text { Lys } \\
0.75 \\
1.00 \\
\%\end{array}$ & $\begin{array}{c}\text { Lys } \\
0.85 \\
1.15 \\
\%\end{array}$ & $\begin{array}{c}\text { Lys } \\
0.55 \\
0.70 \\
\%\end{array}$ & $\begin{array}{c}\text { Lys } \\
0.65 \\
0.85 \\
\%\end{array}$ & $\begin{array}{c}\text { Lys } \\
0.75 \\
1.00 \\
\%\end{array}$ & $\begin{array}{c}\text { Lys } \\
0.85 \\
1.15 \\
\%\end{array}$ & & E & $\mathbf{L}$ & I \\
\hline \multicolumn{13}{|l|}{ Body weight $(\mathrm{kg})$} \\
\hline $35 d$ & 167.9 & 167.0 & 167.8 & 168.8 & 169.1 & 168.1 & 167.9 & 162.5 & 9.91 & 0.74 & 0.91 & 0.77 \\
\hline $110 \mathrm{~d}$ & 199.0 & 196.0 & 192.6 & 190.6 & 200.6 & 194.8 & 196.0 & 202.2 & 13.15 & 0.36 & 0.79 & 0.72 \\
\hline BW gain $(35-110 d)$ & 31.1 & 29.0 & 24.8 & 21.8 & 31.5 & 26.7 & 28.1 & 39.7 & 10.61 & 0.07 & 0.56 & 0.25 \\
\hline 24 hrs postpartum & 179.5 & 183.7 & 167.2 & 168.2 & 172.9 & 173.0 & 174.7 & 181.1 & 12.39 & 0.85 & 0.69 & 0.16 \\
\hline Day 21 of lactation & 163.4 & 177.8 & 155.1 & 165.0 & 168.9 & 173.3 & 183.9 & 178.5 & 16.06 & 0.09 & 0.75 & 0.36 \\
\hline BW loss (0-21 d) & -16.1 & -5.9 & -12.1 & -3.2 & -4.0 & 0.3 & 9.2 & -2.6 & 12.65 & 0.05 & 0.57 & 0.51 \\
\hline \multicolumn{13}{|l|}{ Backfat thickness (mm) } \\
\hline $35 d$ & 24.9 & 24.5 & 25.1 & 23.7 & 23.7 & 25.6 & 27.1 & 23.2 & 4.72 & 0.80 & 0.64 & 0.86 \\
\hline $110 d$ & 23.9 & 25.8 & 24.1 & 24.2 & 28.2 & 26.2 & 26.8 & 26.2 & 4.26 & 0.10 & 0.96 & 0.80 \\
\hline BF gain (35-110 d) & -1.0 & 1.3 & -1.0 & 0.5 & 4.5 & 0.6 & -0.3 & 3.0 & 4.79 & 0.21 & 0.64 & 0.54 \\
\hline $24 \mathrm{hrs}$ postpartum & 22.6 & 24.5 & 23.8 & 25.0 & 27.7 & 26.5 & 25.9 & 26.7 & 3.99 & 0.04 & 0.95 & 0.76 \\
\hline Day 21 of lactation & 19.2 & 20.6 & 19.3 & 20.6 & 23.1 & 21.4 & 21.8 & 23.5 & 4.17 & 0.07 & 0.88 & 0.88 \\
\hline BF loss $(0-21 d)$ & -3.4 & -3.9 & -4.5 & -4.4 & -4.6 & -5.1 & -4.1 & -3.2 & 2.87 & 0.81 & 0.96 & 0.76 \\
\hline Lactational feed intake $(\mathrm{kg} / \mathrm{d})$ & 4.81 & 5.45 & 5.21 & 4.91 & 5.18 & 5.19 & 5.21 & 4.42 & 0.868 & 0.74 & 0.39 & 0.71 \\
\hline WEI (d) & 5.20 & 5.33 & 5.25 & 5.33 & 4.50 & 6.75 & 4.33 & 5.00 & 0.811 & 0.70 & 0.03 & 0.06 \\
\hline
\end{tabular}

${ }^{1)}$ Factors: energy level (3,265 or 3,365 kcal of ME/kg) and lysine level (total lysine $\left.0.55 / 0.70 \%, 0.65 / 0.85 \%, 0.75 / 1.00 \%, 0.85 / 1.15 \%\right)$ in gestation/lactation diet.

WEI, weaning-to-estrus interval; ME, metabolizable energy; Lys, lysine; SEM, standard error of the mean; E, energy effect. L, lysine effect. I, interaction between energy and lysine effects.

\section{RESULTS}

The effects of dietary energy and lysine levels on BW and BF thickness of primiparous sows were presented in Table 3. The BW gain $(p=0.07)$ and backfat thickness $(p=0.09)$ in the gestation period showed a tendency to be increased in sows fed the high-energy diets. However, the BW loss of sows fed the high-energy diets tended to be less than that of sows fed the low-energy diets in lactation period $(p=0.05)$. The sows fed high energy diets had greater BF thickness than that of sows fed low energy diets on 24 hrs postpartum $(p=0.04)$, and showed a tendency to be increased in $\mathrm{BF}$ thickness on day 21 of lactation $(p=0.07)$. However, the lactation daily feed intake was not affected by dietary energy and lysine levels. Sows fed the Lys $0.55 \% / 0.70 \%$ and Lys $0.75 \% / 1.00 \%$ diet showed a shorter WEI than sows in the other treatment groups $(p=0.03)$.

The effects of dietary energy and lysine levels on reproductive performance and growth of their progeny were shown in Tables 4 and 5, respectively. Dietary energy and lysine levels tended to interact on the number of total born and born alive such that sows fed low energy diets decreased the number of total born and born alive piglets, but sows fed high energy diets increased the number of total born and born alive piglets ( $p<0.01$, and $p=0.04$, respectively). The number of mummy was greater in the Lys $0.65 / 0.85$ group and lower in the Lys $0.85 / 1.15$ group $(p=0.01)$. There were no significant differences in total litter weight and alive litter weight. However, alive piglet weight was decreased in the high-energy group and increased in the low-energy group $(p=0.02)$. The piglet uniformity, such as $\mathrm{SD}$ and $\mathrm{CV}$ of piglet weight, and ratio of irregular birth weight at farrowing, were not affected by dietary energy and lysine levels for gestation diets. Litter weight and litter weight gain during lactation were not affected by dietary energy and lysine levels. However, piglet weight on day 21 of lactation and piglet weight gain for high energy diets tended to be increased 
Table 4. Effects of dietary energy and lysine levels on reproductive performance in primiparous sows

\begin{tabular}{|c|c|c|c|c|c|c|c|c|c|c|c|c|}
\hline \multirow[b]{2}{*}{ Item $^{1)}$} & \multicolumn{4}{|c|}{ ME $3,265 \mathrm{kcal} / \mathrm{kg}$} & \multicolumn{4}{|c|}{ ME 3,365 kcal/kg } & \multirow[b]{2}{*}{ SEM } & \multicolumn{3}{|c|}{$p$-value } \\
\hline & $\begin{array}{c}\text { Lys } \\
0.55 \\
0.70 \\
\%\end{array}$ & $\begin{array}{c}\text { Lys } \\
0.65 \\
0.85 \\
\%\end{array}$ & $\begin{array}{c}\text { Lys } \\
0.75 \\
1.00 \\
\%\end{array}$ & $\begin{array}{c}\text { Lys } \\
0.85 \\
1.15 \\
\%\end{array}$ & $\begin{array}{c}\text { Lys } \\
0.55 \\
0.70 \\
\%\end{array}$ & $\begin{array}{c}\text { Lys } \\
0.65 \\
0.85 \\
\%\end{array}$ & $\begin{array}{c}\text { Lys } \\
0.75 \\
1.00 \\
\%\end{array}$ & $\begin{array}{c}\text { Lys } \\
0.85 \\
1.15 \\
\%\end{array}$ & & E & $\mathbf{L}$ & I \\
\hline \multicolumn{13}{|l|}{ No. of piglets } \\
\hline Total born & 13.1 & 16.0 & 13.5 & 9.6 & 12.4 & 8.2 & 13.0 & 12.8 & 3.10 & 0.17 & 0.53 & $<.01$ \\
\hline Stillborn & 1.0 & 0.8 & 0.0 & 0.4 & 0.4 & 0.6 & 0.7 & 0.3 & 0.78 & 0.90 & 0.72 & 0.50 \\
\hline Mummy & 0.1 & 2.2 & 0.0 & 0.0 & 0.2 & 0.6 & 0.7 & 0.0 & 0.70 & 0.45 & 0.01 & 0.10 \\
\hline Born alive & 12.0 & 13.0 & 13.5 & 9.2 & 11.8 & 7.0 & 11.6 & 12.5 & 3.10 & 0.29 & 0.40 & 0.04 \\
\hline \multicolumn{13}{|l|}{ Litter weight (kg) } \\
\hline Total litter weight & 15.40 & 16.79 & 16.58 & 12.98 & 15.34 & 10.70 & 15.10 & 14.64 & 3.53 & 0.24 & 0.54 & 0.18 \\
\hline Alive litter weight & 14.43 & 14.63 & 16.57 & 12.58 & 15.00 & 10.14 & 14.00 & 14.31 & 3.68 & 0.38 & 0.46 & 0.37 \\
\hline Alive piglet weight & 1.23 & 1.13 & 1.22 & 1.37 & 1.29 & 1.51 & 1.22 & 1.16 & 0.17 & 0.35 & 0.79 & 0.02 \\
\hline \multicolumn{13}{|c|}{ Piglet uniformity on farrowing } \\
\hline SD & 222.9 & 218.5 & 198.6 & 232.6 & 271.5 & 169.1 & 247.7 & 233.3 & 77.66 & 0.62 & 0.51 & 0.48 \\
\hline CV & 19.0 & 19.5 & 16.4 & 17.6 & 21.7 & 13.2 & 20.5 & 21.1 & 6.95 & 0.65 & 0.64 & 0.36 \\
\hline Piglets < $800 \mathrm{~g}(\%)$ & 9.5 & 7.3 & 3.0 & 5.6 & 8.0 & 12.6 & 13.2 & 9.8 & 12.40 & 0.31 & 0.98 & 0.82 \\
\hline Piglets > 1,600 g (\%) & 12.8 & 2.0 & 1.5 & 19.0 & 11.8 & 34.4 & 9.8 & 4.5 & 15.51 & 0.32 & 0.60 & 0.08 \\
\hline
\end{tabular}

${ }^{1)}$ Factors: energy level (3,265 or 3,365 kcal of ME/kg) and lysine level (total lysine $\left.0.55 / 0.70 \%, 0.65 / 0.85 \%, 0.75 / 1.00 \%, 0.85 / 1.15 \%\right)$ in gestation/lactation diet.

ME, metabolizable energy; Lys, lysine; SEM, standard error of the mean; E, energy effect; L, lysine effect; I, interaction between energy and lysine effect; SD, standard deviation; CV, coefficient of variation.

Table 5. Effects of dietary energy and lysine levels on growth of progeny in primiparous sows

\begin{tabular}{|c|c|c|c|c|c|c|c|c|c|c|c|c|}
\hline \multirow[b]{2}{*}{ Item $^{1)}$} & \multicolumn{4}{|c|}{ ME $3,265 \mathrm{kcal} / \mathrm{kg}$} & \multicolumn{4}{|c|}{ ME 3,365 kcal/kg } & \multirow[b]{2}{*}{ SEM } & \multicolumn{3}{|c|}{$p$-value } \\
\hline & $\begin{array}{c}\text { Lys } \\
0.55 \\
0.70 \\
\%\end{array}$ & $\begin{array}{c}\text { Lys } \\
0.65 \\
0.85 \\
\%\end{array}$ & $\begin{array}{c}\text { Lys } \\
0.75 \\
1.00 \\
\%\end{array}$ & $\begin{array}{c}\text { Lys } \\
0.85 \\
1.15 \\
\%\end{array}$ & $\begin{array}{c}\text { Lys } \\
0.55 \\
0.70 \\
\%\end{array}$ & $\begin{array}{c}\text { Lys } \\
0.65 \\
0.85 \\
\%\end{array}$ & $\begin{array}{c}\text { Lys } \\
0.75 \\
1.00 \\
\%\end{array}$ & $\begin{array}{c}\text { Lys } \\
0.85 \\
1.15 \\
\%\end{array}$ & & $\mathbf{E}$ & $\mathbf{L}$ & $\mathbf{I}$ \\
\hline \multicolumn{13}{|l|}{ No. of piglets } \\
\hline After fostering & 11.6 & 11.3 & 11.5 & 11.6 & 11.4 & 11.2 & 11.5 & 11.5 & 0.65 & 0.63 & 0.70 & 0.97 \\
\hline $21 \mathrm{~d}$ of lactation & 10.8 & 11.2 & 11.5 & 10.6 & 10.6 & 10.8 & 10.2 & 10.2 & 1.22 & 0.17 & 0.77 & 0.82 \\
\hline \multicolumn{13}{|l|}{ Litter weight (kg) } \\
\hline After fostering & 13.95 & 12.65 & 13.84 & 15.56 & 14.42 & 15.84 & 14.26 & 13.69 & 1.625 & 0.36 & 0.90 & 0.04 \\
\hline Day 21 of lactation & 54.16 & 55.75 & 61.02 & 56.44 & 58.41 & 60.18 & 58.12 & 54.95 & 9.687 & 0.74 & 0.83 & 0.79 \\
\hline Weight gain $(0-21 \mathrm{~d})$ & 40.21 & 43.10 & 47.18 & 40.88 & 43.99 & 44.34 & 43.86 & 41.26 & 8.761 & 0.86 & 0.72 & 0.85 \\
\hline \multicolumn{13}{|l|}{ Piglet weight (kg) } \\
\hline After fostering & 1.19 & 1.13 & 1.21 & 1.34 & 1.27 & 1.41 & 1.24 & 1.19 & 0.159 & 0.25 & 0.90 & 0.07 \\
\hline Day 21 of lactation & 4.98 & 4.98 & 5.31 & 5.30 & 5.54 & 5.65 & 5.77 & 5.35 & 0.740 & 0.08 & 0.85 & 0.81 \\
\hline Weight gain $(0-21 \mathrm{~d})$ & 3.79 & 3.85 & 4.10 & 3.96 & 4.27 & 4.24 & 4.53 & 4.16 & 0.626 & 0.08 & 0.73 & 0.96 \\
\hline \multicolumn{13}{|c|}{ Piglet uniformity on day 21 of lactation } \\
\hline SD & 1,076 & 925 & 1,204 & 1,144 & 944 & 1,037 & 1,067 & 967 & 370.9 & 0.48 & 0.81 & 0.83 \\
\hline CV & 21.8 & 19.9 & 22.7 & 22.0 & 17.1 & 18.6 & 18.8 & 18.6 & 7.83 & 0.19 & 0.97 & 0.96 \\
\hline
\end{tabular}

${ }^{1)}$ Factors: energy level $(3,265$ or $3,365 \mathrm{kcal}$ of $\mathrm{ME} / \mathrm{kg}$ ) and lysine level (total lysine $0.55 / 0.70 \%, 0.65 / 0.85 \%, 0.75 / 1.00 \%, 0.85 / 1.15 \%)$ in gestation/lactation diet.

ME, metabolizable energy; Lys, lysine; SEM, standard error of the mean; E, energy effect; L, lysine effect; I, interaction between energy and lysine effect; SD, standard deviation; CV, coefficient of variation.

than those for low energy diets $(p=0.08)$. As the result of piglet uniformity at farrowing, there were no significant differences in SD and $\mathrm{CV}$ of piglet weight within the same litter at day 21 of lactation. 
Table 6. Effects of dietary energy and lysine levels on blood profiles in primiparous sows

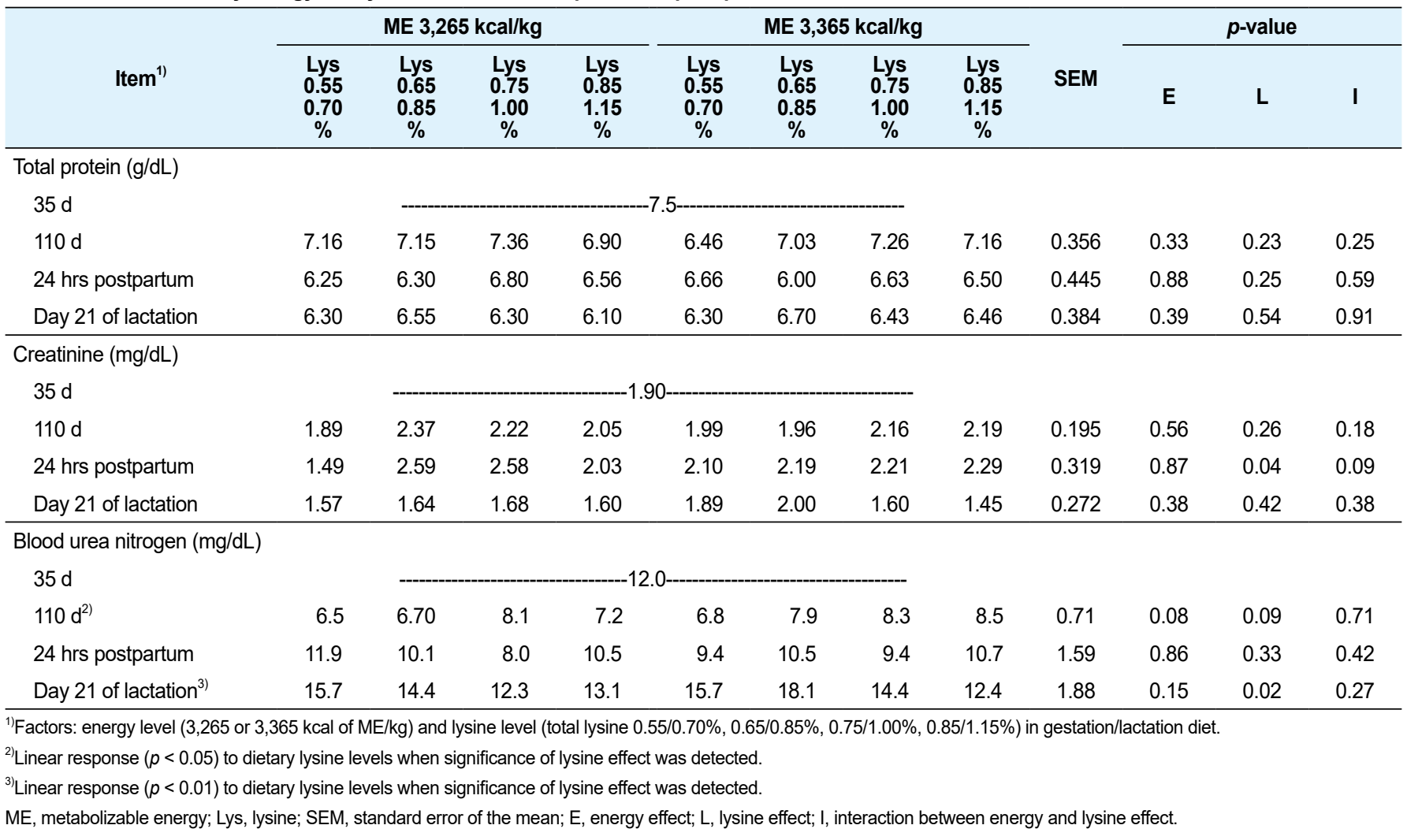

In blood profiles of primiparous sows (Table 6), blood creatinine was greater in Lys 0.65/0.85 and Lys $0.75 / 1.00$ groups on $24 \mathrm{hrs}$ postpartum $(p=0.04)$. The BUN was increased linearly as lysine level increased at day 110 of gestation (Linear, $p=0.03$ ), However, the BUN was decreased linearly as lysine level of diets increased at day 21 of lactation (Linear, $p<0.01$ ) and were significantly lower in the Lys $0.75 / 1.00$ and Lys $0.85 / 1.15$ groups $(p=0.02)$.

In the composition of colostrum (Table 7), sows fed high energy diets had greater contents of casein, protein, total solid, solid not fat, and free fatty acid than those of sows fed low energy diets $(p=0.03, p=0.03, p=0.03, p=0.03$, and $p<0.01$, respectively). Otherwise, the lactose level of colostrum was lower in the high-energy group $(p=0.02)$; however, the lactose level in milk on day 21 of lactation was higher in the high-energy group $(p=0.04)$. For the lysine effect, the free fatty acid level of milk for Lys 0.75/1.00 and Lys 0.85/1.15 groups were greater than that for Lys $0.65 / 0.85$ ( $p$ $=0.01$ ).

\section{DISCUSSION}

In the current study, high energy intake resulted in greater BW gain during gestation, and greater BW, BF thickness, and less BW loss during lactation. Increased energy intake from 3,100 to 3,400 $\mathrm{kcal}$ of $\mathrm{ME} / \mathrm{kg}$ during gestation in primiparous sows resulted in greater BW gain [26,27]. Heo et al. [18] showed that dietary energy levels $(3,265,3,330$, and 3,400 kcal of $\mathrm{ME} / \mathrm{kg})$ did not affect the gestation BW and BF thickness, but there were greater BW loss and BF loss of sows for low energy treatment during the lactation period. Thus, the high energy diet led to greater BW and BF gain during gestation compared to the low energy diet. There were no lysine effects on $\mathrm{BW}$ and $\mathrm{BF}$ thickness during gestation in primiparous sows, which was in agreement with the Cooper et al. [28] 
Table 7. Effects of dietary energy and lysine levels on milk composition in primiparous sows

\begin{tabular}{|c|c|c|c|c|c|c|c|c|c|c|c|c|}
\hline \multirow[b]{2}{*}{ Item $^{1)}$} & \multicolumn{4}{|c|}{ ME 3,265 kcal/kg } & \multicolumn{4}{|c|}{ ME $3,365 \mathrm{kcal} / \mathrm{kg}$} & \multirow[b]{2}{*}{ SEM } & \multicolumn{3}{|c|}{$p$-value } \\
\hline & $\begin{array}{c}\text { Lys } \\
0.55 \\
0.70 \\
\%\end{array}$ & $\begin{array}{c}\text { Lys } \\
0.65 \\
0.85 \\
\%\end{array}$ & $\begin{array}{c}\text { Lys } \\
0.75 \\
1.00 \\
\%\end{array}$ & $\begin{array}{c}\text { Lys } \\
0.85 \\
1.15 \\
\%\end{array}$ & $\begin{array}{c}\text { Lys } \\
0.55 \\
0.70 \\
\%\end{array}$ & $\begin{array}{c}\text { Lys } \\
0.65 \\
0.85 \\
\%\end{array}$ & $\begin{array}{c}\text { Lys } \\
0.75 \\
1.00 \\
\%\end{array}$ & $\begin{array}{c}\text { Lys } \\
0.85 \\
1.15 \\
\%\end{array}$ & & E & $\mathbf{L}$ & I \\
\hline \multicolumn{13}{|l|}{ Casein $(\%)$} \\
\hline Colostrum & 5.25 & 4.52 & 7.06 & 6.08 & 7.34 & 7.70 & 9.38 & 6.53 & 1.929 & 0.03 & 0.31 & 0.74 \\
\hline Milk (21 d) & 4.57 & 4.51 & 4.65 & 4.41 & 4.54 & 4.36 & 4.71 & 4.51 & 0.251 & 0.95 & 0.48 & 0.89 \\
\hline \multicolumn{13}{|l|}{ Fat (\%) } \\
\hline Colostrum & 9.45 & 7.89 & 7.56 & 8.11 & 7.87 & 10.19 & 6.21 & 7.07 & 1.371 & 0.54 & 0.12 & 0.17 \\
\hline Milk (21 d) & 6.13 & 6.93 & 7.80 & 6.66 & 7.87 & 6.33 & 8.3 .1 & 6.82 & 0.930 & 0.35 & 0.16 & 0.38 \\
\hline \multicolumn{13}{|l|}{ Protein (\%) } \\
\hline Colostrum & 6.50 & 5.61 & 9.18 & 7.76 & 9.57 & 9.98 & 12.40 & 8.45 & 2.644 & 0.03 & 0.29 & 0.74 \\
\hline Milk (21 d) & 5.04 & 4.91 & 5.02 & 4.76 & 4.83 & 4.82 & 5.37 & 5.05 & 0.308 & 0.61 & 0.50 & 0.56 \\
\hline \multicolumn{13}{|l|}{ Lactose (\%) } \\
\hline Colostrum & 4.48 & 4.83 & 4.10 & 4.32 & 4.04 & 4.09 & 3.57 & 4.21 & 0.374 & 0.02 & 0.13 & 0.67 \\
\hline Milk (21 d) & 5.95 & 6.04 & 6.03 & 6.08 & 5.78 & 5.83 & 5.28 & 5.95 & 0.220 & 0.04 & 0.34 & 0.39 \\
\hline \multicolumn{13}{|l|}{ Total solid (\%) } \\
\hline Colostrum & 22.44 & 20.06 & 23.54 & 22.54 & 24.49 & 27.44 & 25.70 & 22.13 & 2.671 & 0.03 & 0.62 & 0.18 \\
\hline Milk (21 d) & 18.60 & 19.10 & 20.17 & 18.67 & 19.95 & 18.28 & 20.61 & 19.13 & 1.108 & 0.51 & 0.16 & 0.58 \\
\hline \multicolumn{13}{|l|}{ Solid not fat (\%) } \\
\hline Colostrum & 11.17 & 10.58 & 13.54 & 12.35 & 14.00 & 14.16 & 16.51 & 12.91 & 2.398 & 0.03 & 0.31 & 0.78 \\
\hline Milk (21 d) & 11.37 & 11.17 & 11.19 & 11.03 & 10.93 & 10.96 & 10.95 & 11.08 & 0.306 & 0.23 & 0.97 & 0.78 \\
\hline \multicolumn{13}{|l|}{ Free fatty acid (\%) } \\
\hline Colostrum & 3.44 & 3.35 & 4.17 & 3.40 & 4.23 & 3.53 & 4.35 & 4.62 & 0.319 & $<.01$ & 0.01 & 0.06 \\
\hline Milk (21 d) & 5.54 & 5.49 & 4.65 & 6.16 & 6.37 & 5.25 & 5.43 & 4.85 & 0.848 & 0.96 & 0.44 & 0.21 \\
\hline
\end{tabular}

${ }^{11}$ Factors: energy level $(3,265$ or $3,365 \mathrm{kcal}$ of $\mathrm{ME} / \mathrm{kg}$ ) and lysine level (total lysine $0.55 / 0.70 \%, 0.65 / 0.85 \%, 0.75 / 1.00 \%, 0.85 / 1.15 \%)$ in gestation/lactation diet.

$\mathrm{ME}$, metabolizable energy; Lys, lysine; SEM, standard error of the mean; E, energy effect; L, lysine effect; I, interaction between energy and lysine effect.

study. They reported that the level of dietary lysine (average of 10.6 and $13.2 \mathrm{~g}$ total lysine/d) during gestation did not affect gestation BW gain. Otherwise, supplementation with $16 \mathrm{~g} / \mathrm{d}$ of lysine increased BW gain in primiparous sows during gestation compared with sows fed 4 or $8 \mathrm{~g} / \mathrm{d}$ of lysine [29]. Total lysine intake during gestation in the current study was $11,13,15$, and $17 \mathrm{~g} / \mathrm{d}$; these values were at or above the nutrient recommendations (9.4-11.4 $\mathrm{g}$ and 12.4-19.3 $\mathrm{g}$ of total lysine/ d) of the 1998 NRC guidelines [24] and the 2012 NRC guidelines [25], respectively. Thus, the current results demonstrated that the recommendations of the NRC in both 1998 [24] and 2012 [25], with respect to daily lysine intake, were adequate. Although there was no significant difference in BW and BF changes during lactation in the current study, Yang et al. [14] demonstrated that high-lysine intake (1.6\% vs. $1.0 \%$ vs. $0.4 \%)$ during lactation reduced BW loss; and, lysine intake during lactation did not affect $\mathrm{BF}$ change during the entire lactation period. Also, Knabe et al. [30] demonstrated that various lysine diets $(0.6 \%, 0.75 \%$, and $0.9 \%$ total lysine) had no influence on BW and $\mathrm{BF}$ loss during lactation. According to the results that were reported by Jones and Stahly [13] and Yang et al. [14], low lysine intake had no significant influence on BF loss during lactation, but muscle protein degradation for sows tended to be increased due to the insufficient protein intake for milk production. Moreover, Prunier et al. [31] observed that the energy and nitrogen contents in milk were similar in primiparous sows fed 2.5 or $5.5 \mathrm{~kg}$ of feed per day during lactation, which was in accordance with the observation in primiparous sows fed 67.3 or $40.1 \mathrm{~kJ} \mathrm{ME} / \mathrm{d}$ during lactation; however, these low intakes of energy and feed resulted in severe BW and BF loss of primiparous 
sows.

In the current study, there was an interaction between energy and lysine effect in the number of piglet birth and alive piglet weight. These results were from the lower number of piglet birth in Lys $0.85 / 1.15$ with $3,265 \mathrm{kcal}$ of ME/ $\mathrm{kg}$ treatment and Lys $0.65 / 0.85$ with $3,365 \mathrm{kcal}$ of ME/ $\mathrm{kg}$ treatment. There were some possible reasons for these results; one possibility is that these results were not from the dietary factors, but were influenced by the ovulation rate and fetal survival of individual primiparous sows before the experiment started. Cooper et al. [28] reported that increased lysine intake in the gestation diet had no significant effects on litter size and growth; however, total births and total litter weight were affected by parities. They observed that gestation energy intake showed a positive relationship with the number of piglets born alive and litter weight at birth in multiparous sows, but not in primiparous sows because primiparous sows were still growing to mature size. The other possibility was that the amino acid imbalance affected the results. The total lysine levels of the diets were adjusted on each treatment with the same amount of limiting amino acids (methionine, threonine, and tryptophan). This imbalance of amino acids may result in an unexpected number of piglet births and piglet birth weight. Touchette et al. [32] demonstrated that increasing lysine levels with the constant ideal amino acid ratios to first parity sows reduced the number of total born and born alive piglets on subsequent parity. Cooper et al. [28] reported that different lysine intake ( $0.44 \%$ or $0.55 \%$ total lysine) did not affect litter size for total born and born alive, litter birth weight, nor piglet birth weight. Thus, various energy and lysine intake during gestation had no significant effect on litter size, litter weight, and piglet weight at birth in primiparous sows

Litter growth was improved by greater milk production with the high energy diet [12,33] and greater lactation feed intake [34]. In the current study, the dietary energy effect was observed in piglet weight gain and piglet weight on day 21 of lactation, not in litter weight and gain. Considering the results for colostrum content, lactation feed intake, and BW loss during lactation, the 3,365 kcal of $\mathrm{ME} / \mathrm{kg}$ diet met the energy requirement of sows for milk production and maternal gain and the growth of their progeny rather than the $3,265 \mathrm{kcal}$ of $\mathrm{ME} / \mathrm{kg}$ diet. In addition, these results suggested that the energy effect on litter weight was not observed due to litter size during lactation and feeding ad libitum.

In the present study, sows fed $0.7 \%, 0.85 \%, 1.0 \%$, or $1.15 \%$ total lysine with different energy diets $(3,265$ or 3,365 kcal of ME/ $\mathrm{kg}$ ) consumed, on average, $33.7 \mathrm{~g} / \mathrm{d}, 46.3 \mathrm{~g} / \mathrm{d}, 52.1 \mathrm{~g} / \mathrm{d}$, and 56.5 $\mathrm{g} / \mathrm{d}$ of total lysine, respectively, on the 3,265 ME kcal/ $\mathrm{kg}$ diet, and $36.3 \mathrm{~g} / \mathrm{d}, 44.1 \mathrm{~g} / \mathrm{d}, 52.1 \mathrm{~g} / \mathrm{d}$, and $50.8 \mathrm{~g} / \mathrm{d}$ of lysine, respectively, on the $3,365 \mathrm{ME} \mathrm{kcal} / \mathrm{kg}$ diet. Previous studies had reported that the maximal response in litter weaning weights or piglet weaning weights was detected at $47 \mathrm{~g} / \mathrm{d}$ of lysine ([35]; sows consumed 20-47 g/d lysine and 10.5 weaned pigs per litter), or $55 \mathrm{~g} / \mathrm{d}$ of lysine ([36]; sows consumed 35-55 g/d lysine and 11.1 weaned pigs per litter). According to the NRC [24], total lysine intake during lactation $(35.3 \mathrm{~g} / \mathrm{d}$ or $48.6 \mathrm{~g} / \mathrm{d})$ met the lysine requirement of lactating sows. According to the NRC [25], total lysine intake during lactation for primiparous sows was 48.7 to $56.5 \mathrm{~g} / \mathrm{d}$ (the daily weight gain of piglets was 190-270 g), and sows were weaning 11 pigs per litter. Taken together, lysine intake that ranged from 33.7 to $52.1 \mathrm{~g} / \mathrm{d}$ met or supported piglet growth with no negative effects. The weaning weight of the piglets in the present study was similar to the results that observed by Touchette et al. [32], Thaler et al. [37], and Santos et al. [38], who reported no improvement in litter performance with increasing lysine intake during lactation. In accordance with Knabe et al. [30], the piglet weights at day 21 of lactation were not increased by feeding a corn-SBM-based diet with $0.9 \%$ lysine and they concluded that a $0.75 \%$ lysine diet met the nutrient needs of the sows or nutrient deficiency limited the sow's ability to respond to the higher lysine intake. In addition, the lack of response to increasing levels of lysine on litter performance (even with the addition of DL-methionine, L-threonine, and L-tryptophan to achieve balance in 
the diets) could be related to a lack of other limiting amino acids [32,38]. Thus, lysine intake during lactation met the minimum lysine requirement or induced amino acid imbalance of lactating sows and did not show any significant differences in litter growth as a result of the lysine effect.

Piglet birth weight and litter uniformity are important to the growth and mortality of piglets before weaning [39] because low-weight piglets could not intake the sufficient colostrum and have low passive immunity or nutritional status [2], and litters with greater BW variation had more variable weight at weaning and slaughter [40]. There was no significant difference in the SD and $\mathrm{CV}$ of piglet weight at birth and day 21 of lactation because of pre-mating factors and maternal nutrition during gestation [41,42]. Before gilts mate, the development and uniformity of embryos and placenta ultimately affecting litter uniformity can be affected by insufficient restoration of follicle development and increased developmental variation within the preovulatory follicle pool [42]. In addition, Campos et al. [41] reported that maternal nutrition during gestation, such as insulin, IGF-1, and dietary protein or amino acid levels, had an effect on piglet uniformity. Also, the CV of the mean BW was positively related to the BF gain of the sow during gestation [3], but dietary effects were not observed in BF gain during gestation and piglet uniformity in the current study.

The concentration of BUN is known as an indicator of protein mobilization, nitrogen balance [43], and amino acid requirements [44] in sows. Also, creatinine is an indicator of muscle catabolism [18]. Based on the concentrations of creatinine, $0.65 \%$ and $0.75 \%$ lysine in gestation diets had a high efficiency of protein utilization in lactating sows at $24 \mathrm{hrs}$ postpartum. According to the results of BUN, high lysine intake induced excess nitrogen at day 110 of gestation, and the $0.75 \% / 1.00 \%$ lysine group showed high efficiency of nitrogen utilization in lactating sows on $24 \mathrm{hrs}$ postpartum and day 21 of lactation.

Many previous studies reported that the chemical compositions of colostrum and milk were not affected by dietary energy intake during gestation because sows utilize their internal reserves to compensate for deficient nutrients [15,27]. Beyer et al. [45] indicated that colostrum and body reserves were major determinants of milk yield in early lactation, whereas the feed intake of sows becomes important in the later lactation due to the greater exhaustion of their body reserves [45]. The body condition of the sow at farrowing and during lactation plays an important role in milk composition such that the milk fat content was $20 \%$ greater in sows with a high body fat content compared with lean sows [46]. Thus, the high deposition of protein and fat mass in primiparous sows before lactation resulted in high milk components, except lactose, which was delivered from the dam to their progeny using body reserves. Some researchers reported that a high-lysine diet does not affect milk composition [47,48], whereas others insist that a high-lysine diet increases milk components $[13,18,29]$. In the current study, the lysine effect was observed only in free fatty acids of colostrum. Milk fat was manufactured in the mammary gland from glycerol and free fatty acids [49], and the lysine requirement to maximize the milk production was increased as ME intake increased [12]. Therefore, the high-energy group had greater free fatty acid content in colostrum compared with the low-energy group, and sows fed the $0.75 \%$ lysine diet had the highest free fatty acids content in the colostrum.

\section{CONCLUSION}

In conclusion, the primiparous sows fed the diet containing 3,365 kcal of ME/ $/ \mathrm{kg}$ had more gain of BW and BF compared with sows fed the diet containing 3,265 kcal of ME/kg. Also, piglets from sows fed the $3,365 \mathrm{kcal}$ of $\mathrm{ME} / \mathrm{kg}$ diet showed greater piglet weight gain during lactation. Although significant differences were not observed in reproductive performance and piglet uniformity, total lysine $0.75 \%$ for gestation and $1.00 \%$ for lactation showed higher nitrogen utilization in 
the blood profile of sows. Moreover, the WEI was decreased in the Lys $0.75 / 1.00$ group. Thus, the supplementation of total lysine $0.75 \%$ for gestation and $1.00 \%$ for lactation in $3,365 \mathrm{kcal}$ of ME/ $\mathrm{kg}$ could be applied to the primiparous sows' diet to improve sow performance and piglet growth.

\section{REFERENCES}

1. Foxcroft GR, Dixon WT, Novak S, Putman CT, Town SC, Vinsky MDA. The biological basis for prenatal programming of postnatal performance in pigs. J Anim Sci. 2006;84:E105-12.

2. Wolf J, Žáková E, Groeneveld E. Within-litter variation of birth weight in hyperprolific Czech large white sows and its relation to litter size traits, stillborn piglets and losses until weaning. Livest Sci. 2008;115:195-205.

3. Quesnel H, Brossard L, Valancogne A, Quiniou N. Influence of some sow characteristics on within-litter variation of piglet birth weight. Animal. 2008;2:1842-9.

4. De Vos M, Che L, Huygelen V, Willemen S, Michiels J, Van Cruchten S, et al. Nutritional interventions to prevent and rear low-birthweight piglets. J Anim Physiol Anim Nutr. 2014;98:609-19.

5. King RH. Nutritional anoestrus in young sows. Pig News Info. 1987;8:15-22.

6. Young LG, King GJ, Walton JS, McMillan I, Klevorick M. Age, weight, backfat and time of mating effects on performance of gilts. Can J Anim Sci. 1990;70:469-81.

7. Van den Brand H, Dieleman SJ, Soede NM, Kemp B. Dietary energy source at two feeding levels during lactation of primiparous sows: I. effects on glucose, insulin, and luteinizing hormone and on follicle development, weaning-to-estrus interval, and ovulation rate. J Anim Sci. 2000;78:396-404.

8. Ruiz ME, Speer VC, Hays VW, Switzer WP. Effect of feed intake and antibiotic on reproduction in gilts. J Anim Sci. 1968;27:1602-06.

9. Dourmad JY. Effect of feeding level in the gilt during pregnancy on voluntary feed intake during lactation and changes in body composition during gestation and lactation. Livest Prod Sci. 1991;27:309-19.

10. Zak LJ, Cosgrove JR, Aherne FX, Foxcroft GR. Pattern of feed intake and associated metabolic and endocrine changes differentially affect postweaning fertility in primiparous lactating sows. J Anim Sci. 1997;75:208-16.

11. King RH, Martin GB. Relationships between protein intake during lactation, LH levels and oestrous activity in first-litter sows. Anim Reprod Sci. 1989;19:283-92.

12. Tokach MD, Pettigrew JE, Dial GD, Wheaton JE, Crooker BA, Johnston LJ. Characterization of luteinizing hormone secretion in the primiparous, lactating sow: relationship to blood metabolites and return-to-estrus interval.J Anim Sci. 1992;70:2195-201.

13. Jones DB, Stahly TS. Impact of amino acid nutrition during lactation on body nutrient mobilization and milk nutrient output in primiparous sows.J Anim Sci. 1999;77:1513-22.

14. Yang H, Foxcroft GR, Pettigrew JE, Johnston LJ, Shurson GC, Costa AN, et al. Impact of dietary lysine intake during lactation on follicular development and oocyte maturation after weaning in primiparous sows. J Anim Sci. 2000;78:993-1000.

15. Yang Y, Heo S, Jin Z, Yun J, Shinde P, Choi J, et al. Effects of dietary energy and lysine intake during late gestation and lactation on blood metabolites, hormones, milk composition and reproductive performance in multiparous sows. Arch Anim Nutr. 2008;62:10-21.

16. Zhang RF, Hu Q, Li PF, Xue LF, Piao XS, Li DF. Effects of lysine intake during middle to late gestation (day 30 to 110) on reproductive performance, colostrum composition, blood metabolites and hormones of multiparous sows. Asian-Australas J Anim Sci. 2011;24:1142-7. 
17. Eissen JJ, Apeldoorn EJ, Kanis E, Verstegen MWA, De Greef KH. The importance of a high feed intake during lactation of primiparous sows nursing large litters. J Anim Sci. 2003;81:594603.

18. Heo S, Yang YX, Jin Z, Park MS, Yang BK, Chae BJ. Effects of dietary energy and lysine intake during late gestation and lactation on blood metabolites, hormones, milk compositions and reproductive performance in primiparous sows. Can J Anim Sci. 2008;88:247-55.

19. Kim SW, Hurley WL, Wu G, Ji F. Ideal amino acid balance for sows during gestation and lactation. J Anim Sci. 2009;87:E123-32.

20. Kim SW, Mateo RD, Yin YL, Wu G. Functional amino acids and fatty acids for enhancing production performance of sows and piglets. Asian-Australas J Anim Sci. 2007;20:295-306.

21. Andersson E, Frössling J, Engblom L, Algers B, Gunnarsson S. Impact of litter size on sow stayability in Swedish commercial piglet producing herds. Acta Vet Scand. 2016;58:31.

22. Gruhot TR, Díaz JAC, Baas TJ, Stalder KJ. Using first and second parity number born alive information to estimate later reproductive performance in sows. Livest Sci. 2017;196:22-7.

23. Fuller MF, McWilliam R, Wang TC, Giles LR. The optimum dietary amino acid pattern for growing pigs. 2. Requirements for maintenance and for tissue protein accretion. Br J Nutr. 1989;62:255-67.

24. National Research Council. Nutrient requirements of swine. 10th ed. Washington, DC: National Academy Press; 1998.

25. National Research Council. Nutrient requirements of swine. 11th ed. Washington, DC: National Academy Press; 2012.

26. Long HF, Ju WS, Piao LG, Kim YY. Effect of dietary energy levels of gestating sows on physiological parameters and reproductive performance. Asian-Australas J Anim Sci. 2010;23:10808.

27. Jin SS, Jung SW, Jang JC, Chung WL, Jeong JH, Kim YY. Effects of dietary energy levels on the physiological parameters and reproductive performance of gestating gilts. Asian-Australas J Anim Sci. 2016;29:1004-12.

28. Cooper DR, Patience JF, Zijlstra RT, Rademacher M. Effect of energy and lysine intake in gestation on sow performance. J Anim Sci. 2001;79:2367-77.

29. Kusina J, Pettigrew JE, Sower AF, White ME, Crooker BA, Hathaway MR. Effect of protein intake during gestation and lactation on the lactational performance of primiparous sows. J Anim Sci. 1999;77:931-41.

30. Knabe DA, Brendemuhl JH, Chiba LI, Dove CR. Supplemental lysine for sows nursing large litters. J Anim Sci. 1996;74:1635-40.

31. Prunier A, Dourmad JY, Etienne M. Feeding level, metabolic parameters and reproductive performance of primiparous sows. Livest Prod Sci. 1993;37:185-96.

32. Touchette KJ, Allee GL, Newcomb MD, Boyd RD. The lysine requirement of lactating primiparous sows. J Anim Sci. 1998;76:1091-7.

33. Noblet J, Etienne M. Effect of energy level in lactating sows on yield and composition of milk and nutrient balance of piglets. J Anim Sci. 1986;63:1888-96.

34. Patterson JL, Smit MN, Novak S, Wellen AP, Foxcroft GR. Restricted feed intake in lactating primiparous sows. I. effects on sow metabolic state and subsequent reproductive performance. Reprod Fertil Dev. 2011;23:889-98.

35. Stahly TS, Cromwell GL, Monegue HJ. Lactational responses of sows nursing large litters to dietary lysine levels. J Anim Sci 1990;68:369.

36. Johnston LJ, Pettigrew JE, Rust JW. Response of maternal-line sows to dietary protein concentration during lactation. J Anim Sci. 1993;71:2151-6. 
37. Thaler RC, Woerman RL, Britzman DB. Effect of lysine level in lactation diets on sow performance and milk composition.J Anim Sci 1992;70:238.

38. Santos JMGD, Moreira I, Martins EN. Lysine and metabolyzable energy requirements of lactating sows for subsequent reproductive performance. Braz Arch Biol Technol. 2006;49:57581.

39. Quiniou N, Dagorn J, Gaudré D. Variation of piglets' birth weight and consequences on subsequent performance. Livest Prod Sci. 2002;78:63-70.

40. Gondret F, Lefaucheur L, Louveau I, Lebret B, Pichodo X, Le Cozler Y. Influence of piglet birth weight on postnatal growth performance, tissue lipogenic capacity and muscle histological traits at market weight. Livest Prod Sci. 2005;93:137-46.

41. Campos PHRF, Silva BAN, Donzele JL, Oliveira RFM, Knol EF. Effects of sow nutrition during gestation on within-litter birth weight variation: a review. Animal. 2012;6:797-806.

42. Wientjes JGM, Soede NM, Knol EF, Van den Brand H, Kemp B. Piglet birth weight and litter uniformity: effects of weaning-to-pregnancy interval and body condition changes in sows of different parities and crossbred lines. J Anim Sci. 2013;91:2099-107.

43. Coma J, Zimmerman DR, Carrion D. Lysine requirement of the lactating sow determined by using plasma urea nitrogen as a rapid response criterion. J Anim Sci. 1996;74:1056-62.

44. King RH, Toner MS, Dove H, Atwood CS, Brown WG. The response of first-litter sows to dietary protein level during lactation.J Anim Sci. 1993;71:2457-63.

45. Beyer M, Jentsch W, Kuhla S, Wittenburg H, Kreienbring F, Scholze H, et al. Effects of dietary energy intake during gestation and lactation on milk yield and composition of first, second and fourth parity sows. Arch Anim Nutr. 2007;61:452-68.

46. Revell DK, Williams IH, Mullan BP, Ranford JL, Smits RJ. Body composition at farrowing and nutrition during lactation affect the performance of primiparous sows: I. voluntary feed intake, weight loss, and plasma metabolites.J Anim Sci. 1998;76:1729-37.

47. Revell DK, Williams IH, Mullan BP, Ranford JL, Smits RJ. Body composition at farrowing and nutrition during lactation affect the performance of primiparous sows: II. milk composition, milk yield, and pig growth. J Anim Sci. 1998;76:1738-43.

48. McNamara JP, Pettigrew JE. Protein and fat utilization in lactating sows: I. effects on milk production and body composition.J Anim Sci. 2002;80:2442-51.

49. Mansbridge RJ, Blake JS. Nutritional factors affecting the fatty acid composition of bovine milk. Br J Nutr. 1997;78:S37-47. 